\title{
The role of universities in the evolution of the Triple Helix culture of innovation network: The case of Malaysia
}

\author{
Azley Abd Razak University of West of England, Bristol \\ Mohammed Saad University of West of England, Bristol
}

\begin{abstract}
Using a qualitative and a case study approach, this paper examines the role of the Malaysian universities and their social relationships with government and industry in the light of the statist, laissez-faire and hybrid characters of the Triple Helix model. Most Malaysian universities are positioned within the statist and laissezfaire variants of the Triple Helix model, where the government is invariably a dominant actor. Overall, universities in Malaysia have made efforts to see social relationships evolve; however, there are still issues to be addressed and difficulties to be overcome with respect to such questions as commercialisation and procedures that would need to evolve within the university for transition to hybrid Triple Helix culture to take root.
\end{abstract}

\section{Introduction}

Following the policy commitment of the Malaysian Government to encourage universities to be entrepreneurial, some of the public universities have set up, or are in the process of setting up commercial arms (a private holding company). Recently, the Government has conferred research university status on its top four local universities. These four universities are designated under the Ninth Malaysia Plan to be the country's first fully fledged research universities. ${ }^{1}$

This paper examines the current role of Malaysian universities and highlights the character and extent of their links with government agencies and industry. It also investigates the key issues to be addressed and the challenges facing Malaysian universities in the course of their evolution as actors in the Triple Helix model. The paper begins with a review of existing literature on the role of universities in the making of knowledge-based economies in developing countries. This is followed with a discussion of the significance of the emergence of the entrepreneurial role of universities and its relevance to the evolutionary process in the Triple Helix system in Malaysia. After a discussion of the positioning the universities in the

\section{Keywords}

Malaysia

statist

laissez-faire and hybrid triple helix

innovation network entrepreneurial university

1 Each university received RM50 million for (USD15 million) research, development and commercialisation activities (The Star 2007). 
course of the evolutionary process of the Triple Helix, the paper concludes with a brief note on the way forward for the development of the Triple helix culture in Malaysia.

\section{The role of universities as driver of the Triple Helix system}

The role of universities has evolved over the past twenty years. According to Gunasekara (2004), universities were once described as 'ivory tower' institutions focusing only on the traditional academic practices of teaching and research, with hardly any serious commitment to addressing questions arising from the socio-economic milieu within which they function. However, the role of universities has become more significant with the emergence of the knowledge-based economy. Today, universities are progressively being viewed as the powerful drivers of innovation and change in science and technology and other creative disciplines (Sharma et al. 2006; DTI 2001). They are responsible for providing graduates with knowledge and skills and have also become the 'seedbed' for new industries, products and services; and this has established them at the hub of business networks in the emerging knowledge economy (DTI/DfEE 2001).

The importance of universities in the era of the knowledge economy has been emphasised by several authors. For Karrison and Zhang (2001: 181), 'assuming that the universities are the main actors in the knowledge generation process, one could interpret the knowledge sector that appears in endogenous growth models as an aggregation of all universities in an economy'. According to Coffield and Williamson (1997), universities have a place in our complex society where new thoughts can be developed and existing wisdom can be challenged.

Mavin and Bryans (2000) notes that universities have a special public role to play in generating contexts in which learning, dialogue and the development of new knowledge can take place. They also assert that universities are distinctively positioned to take part in a role which promotes individuals and their organisations to seriously challenge their ways of working and thinking. According to Gibbons et al. (1994), the forms of knowledge are continuously shifting away from traditional disciplinary lines to new problem-focused themes; and this has contributed to the view that the role of universities has indeed changed from a more idealistic arrangement, focused on the creation of knowledge for its own sake, to an increasingly instrumentalist position (Readings 1996).

Several factors have contributed to this change. These factors include government policies, expectations of the community, the expansion of the higher education sector, technology needs, and the emergence of a distributed knowledge production system, which is referred to as Mode 2 (Gibbons 1998). Mode 2 knowledge production is characterised by the integration of supply and demand factors such that it is diffused throughout the society. Gellner (1994) also notes that the growth of knowledge requires the social framework of an open society where ideas and policies can be talked about and investigated. The mission of universities is to help 
raise an environment of open communication and trust which will facilitate new learning in the partner-organisations (Mavin and Bryans 2000). For Mavis and Bryans (2000), the role of the universities is to facilitate interprofessional dialogue among individuals in the partner organisations that can help the current government aims for 'joined up' policy and produce creative solutions to multi-disciplinary problems in the public sector. They also suggest that universities have to learn assume new roles in response to changing conditions in contemporary society. For example, their role as a community resource is under-recognised and under-utilised. In playing a role in public sector partnerships, universities have to acknowledge that they have much to learn from the partner organisations and that the process of learning and development is not a one-way street. According to Bjamason (2003), it essentially implies close linkages between universities and markets, whether in local economies, regions or nations.

Universities are expected to play a significant role as enablers, even leaders of regional economic and social development and regional innovation systems in the course of the development of the knowledge-based economy (Gunasekara 2004). The role of universities as key players in the process of endogenous or locally based development strategies, and also in the promotion of inward investment has been generally recognised (Charles 2003). Fritsch and Slavtchev (2007) investigated the role of universities as a source of knowledge for regional innovation processes. They concluded that the intensity and quality of the research conducted by universities has a significant effect on regional innovative output. It is thus important for policies promoting regional innovation processes to include capacity building programmes for universities and to place significant emphasis on the intensity, quality and socio-economic relevance of the research conducted in universities (Fritsch and Slavtchev 2007). According to Henry and Pinch (2000), successful regions have been linked with the growth of knowledge-based clusters embedded in communities of knowledge, which are mainly the universities.

\section{Triple Helix Model and the emergence of a new role for the university}

The drivers for the emergence of this new role are the collaborative networks that link private industrial firms, entrepreneurial universities, government organisations, and other public agencies (Etzkowitz and Kloftten 2005). This development has sparked the notion of a third mission, an entrepreneurial role, to support the process of spinning off their research into a network of industrial firms and business ventures (Castells and Hall 1994). The notion of academic entrepreneurialism was later emphasised by several authors such as Etzkowitz, and Leydesdorff (1997) and Gunasekara (2004).

Academic entrepreneurialism is a unique feature of the Triple Helix model, built on the idea that universities taking on a generative role in directing regional economic development through 'academic entrepreneurial' activities that share common characteristics with the traditional 
roles of the industry and the state in economic regulation (Etzkowitz and Leydesdorf 1997, 1999). The roles of universities in this regard are classified as being either generative or developmental in nature (Gunasekara 2004). Universities are expected to ensure that their knowledge-base is exercised on a practical basis particularly in the local or home region (Cooke 2002). However, the Triple Helix model can be viewed as lacking strong theoretical and empirical bases to support the above views (Saad 2004).

Etzkowitz and Leydesdorff (1997: 1) present the Triple Helix model graphically as a 'spiral model of innovation, which is able to capture multiple reciprocal linkages at different stages of the capitalization of the knowledge'; and this will lead to the generation of a network of new structures within each of them, as well as integrating organisations and hybrid organisations like incubator facilities. Etzkowitz and Leydesdorff (1997) have argued that the Triple Helix model will be the key strategy of national or multinational innovation agenda of the new century. For example, Godin and Gingras (2000) state that the Canadian government has for long focused on the need to develop and promote stronger ties between universities and businesses through new policies and strategic programmes.

Although, most of the literature reviewed above relates to developed countries, Charles (2003) claims that universities in developing countries also play a significant role as a knowledge source in the growth of national and regional innovation systems. Saad (2004) and Saad and Zawdie (2005) are less convinced and have explored the main issues and challenges associated with the implementation of innovation strategies based on the nature of the Triple Helix culture in developing countries.

\section{Evolution of the Triple Helix model}

According to Etzkowitz (2003: 302), the evolutionary process in the Triple Helix system involves transition from the 'statist' stage in which government controls academia and industry, to the laissez-faire state of 'arms length' relationship between the three institutional spheres; and finally to the hybrid stage in which each institutional sphere keeps its own distinctive characteristics and at the same time also assumes the role of the others. The evolutionary process underlying the Triple Helix system is graphically depicted in Figure 1 below.

It is at the hybrid stage of the Triple Helix network development that the dynamics of innovation are expected to be fully at work. The problem with the hybrid Triple Helix is that its emergence as an institutional system could be elusive as it involves a complex process based on high level of commitment, understanding and trust between all the three spheres.

In the evolutionary of the development of the Triple Helix culture, collaborative relationships emerge among the three major institutional spheres in which innovation policy is an outcome of interactions among the spheres rather than a prescription from the government or an internal development within an industry. Several authors have attempted to highlight the complexity of collaborative relationships in the context of 


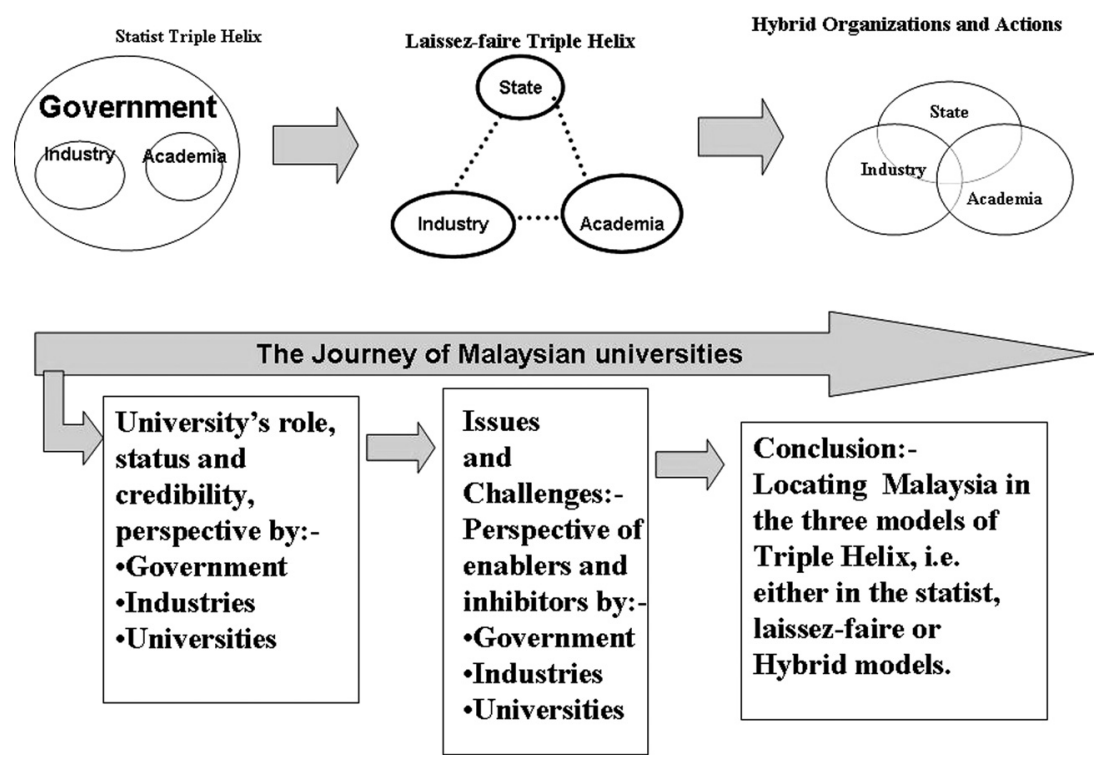

Figure 1: Evolution of the Triple Helix system.

developing countries such as Saad and Zawdie (2005) on Algeria, Sutz (2000) on Latin America, and Malairaja (2003) on Malaysia.

In other words, each helix would be connected to another thus assisting in the formation of interfaces between them. Industry will gain some of the values of the university, sharing as well as protecting knowledge; research groups in industry would collaborate with public and university research groups to achieve common long-term strategic goals (Etzkowitz and Leydesdorff 1997). The stakeholders of the Triple Helix, as well as performing their traditional functions also engage in the roles of the others (Etzkowitz and Leydesdorff 2001). Such a significant role may mean the need to share power with institutions such as universities in developing countries whose status is still not well established.

Triple Helix system emphasises the importance of academia in the capitalisation of knowledge. Godin and Gingras (2000) mentioned that since the mid-90s, universities have been focusing not only on R\&D activities but also on technology transfer to industry. In this dynamic new environment, universities are changing their mission, establishing new relationships with industry and becoming more entrepreneurial (Etzkowitz 1994; Etzkowitz and Leydesdorff 1997). Etzkowitz et al., (2000: 326) define this new type of university as the 'amalgam of teaching and research, applied and basic, entrepreneurial and scholastic interests'. However, to fulfil this new role, universities are expected to acquire some business skills to effectively carry out activities, such as commercialising their research and setting up their own start-ups.

While the Triple Helix system is about interactions and relationships between university, government and industry, as argued by Etzkowitz and Leydesdorff (1997), the factors underlying its organisation and functioning 
2 The four agencies are Invest Penang (a state investment agency), Malaysian Technology Development Corporation Sdn Bhd (MTDC), Small and Medium Industries Development Corporation (SMIDEC), Malaysian Agriculture Research and Development Institute (MARDI) and Kulim High Tech Corporation (owned by a state government). would vary from one country to another. For example, for a developing country like Malaysia, the system may require a reduced role for the government, and greater roles for other institutional bodies such as local public universities, whereas in others, a more active and enhanced role from the government is needed. Regardless of this divergence in underlying organising principle of the Triple Helix system, the importance of the role of universities would need to be recognised as an incremental component of this system in cost reduction, creative invention and technology transfer (Etzkowitz et al 2000).

The above key points arising from the literature review are used as a basis to investigate the role of universities in Malaysia. It will also look into the entrepreneurial culture within the universities and their links with industry and government.

\section{Research methodology}

Our task in this paper is to look into the challenges arising in the evolution of the Triple Helix institutional system in the context of the Malaysian socio-economic environment. This is achieved using a qualitative case study approach. As emphasised by Blaikie (2000), a qualitative approach is appropriate for studies on the dynamics of social relationships like the ones apparent in the Triple Helix phenomenon. A case study approach is an empirical enquiry of a specific phenomenon within its real-life context. Such an approach is useful where the boundaries between the phenomenon and the context are not clearly evident (Yin 1994), as is the case in the Malaysian context. For the purpose of this study, semi-structured interviews were used to elicit information. The samples for the interviews were taken from the three spheres of Triple Helix: the government (government ministries and agencies), universities (for researchers, deputy Vice-Chancellors and staff of research management centres) and industries (managers and executives).

All the eighteen respondents who constituted the sample were carefully selected to represent the position of stakeholders in the evolving Triple Helix institutional culture in Malaysia. The respondents from the universities ranged from researchers to deputy Vice-Chancellors and staff of research management centres. The respondents were from seven different universities, of which four have 'Research University' status. For the government sphere, there were seven respondents in total, of which five were from different government agencies ${ }^{2}$ and the rest from the Ministry of Science, Technology and Innovation (MOSTI). There were four respondents from industry - two from local MNCs and two from international MNCs.

The data obtained from the sample survey were analysed using the thematic analysis approach, which involves transcribing data and identifying patterns that will enable better understanding of the role of each actor and the relationships between the actors in the Triple Helix model, thus establishing the main (Bogdan 1989; Leininger 1989). The next step is to produce a thematic index by cataloguing the sub-themes, and it would not be difficult to 
see patterns emerging from this process (Ritchie and Lewis 2003). What remains after this process is providing the argument for the choice of themes based on a survey of the relevant literature (Ritchie and Lewis 2003).

\section{The state of Malaysian universities in a Triple Helix context}

There is some evidence of entrepreneurial behaviour in Malaysian universities, as, for example, in the establishment of USains Holdings (the university's commercial arm) by the Universiti Sains Malaysia (Malairaja 2003). Almost all top public universities in Malaysia now have their own technology transfer offices (TTO). TTOs are set up to commercialise academic work, generate income from external sources and shape internal research agendas with a view to exploiting the external sources of funding (Macpherson and Ziolkowski 2005). Campbell (2005) believes that TTOs are set up not merely to conduct simple financial transactions, but also to facilitate access to $\mathrm{R} \& \mathrm{D}$ finance, to materials and equipment and to specialist expertise and complementary knowledge. Technology transfer is an important factor in the positive relationship between industrial innovation and the various types of knowledge spillovers reported in the spatial-econometric literature (Varga 1998; Anselin et al. 2000).

Both the Malaysian universities and the Malaysian Government are still having issues about the clarity of the roles and functions of TTOs. One of the issues relates to the ability of the university to provide the policy framework and the financial and human resources required to run TTOs. According to one senior government official, "policy is important to ensure continuity and availability of credible, qualified and knowledgeable people at the interface organisation'.

The need to better define the role of the universities in Malaysia has been recognised not only by the universities themselves but also by the Government. Recently, the Malaysian Government has introduced the concept of 'Research University' under the 9th Malaysian Plan (The Star 2007). The top four major universities in Malaysia have already been granted the status of Research University. ${ }^{3}$ This new status will allow universities to receive more financial support and staff to be granted more support and benefits. However, there are still on-going discussions about the clarity of the mission of these research universities.

There is evidence from the fieldwork supporting the claim that universities in Malaysia have good, credible and capable researchers (Malairaja 2003). Most respondents stated that universities in Malaysia are striving to establish active relationships with the industry. However, these relationships are more related to educational development, consultancy and training. The university is seen by respondents from both the government and industry as an institution that can provide consultations and advice (mostly based on technical expertise). The Government also uses universities to implement its policies.

However, the respondents from the industry appear doubtful about the attitude of universities towards changes and about the nature of universities are Universiti Malaya, Universiti Sains Malaysia (Malaysia University of Science), Universiti Kebangsaan Malaysia (National University of Malaysia) and Universiti Putra Malaysia. 
relationships between universities and industry. This view is also echoed by those on university staff and from government agencies who believe that administrative procedures and structures impose a constraint on the development of strong and trusting relationships between university, government and industry. According to one Vice Chancellor, universities can address this problem can creatively and flexibly with universities. However, in Malaysia, universities are constrained the preponderance of bureaucracy and the absence of teamwork and partnership culture (Malairaja 2003, Saad and Zawdie 2005). Moreover, as highlighted by a senior manager of the commercial arms of one of the universities, 'the university's TTO does not have the right people with the right expertise for the job'. The culture of partnership within a university seems to be also impeded by the high level of competition among the universities and also among researchers. According to one senior government official, 'everybody wants to compete and to show who is best'. Table 1 below presents a summary of the views on the role of universities and their interactions with government and the industry.

\begin{tabular}{|c|c|c|c|c|c|}
\hline Role of universities & $\begin{array}{c}\text { Status of } \\
\text { universities }\end{array}$ & $\begin{array}{l}\text { Credibility and } \\
\text { capabilities }\end{array}$ & $\begin{array}{l}\text { Procedures and } \\
\text { structures }\end{array}$ & $\begin{array}{c}\text { Culture of } \\
\text { partnership within } \\
\text { universities }\end{array}$ & $\begin{array}{c}\text { Type of relationship } \\
\text { with government } \\
\text { and industry }\end{array}$ \\
\hline $\begin{array}{l}\text { Clear evidence } \\
\text { of the desire } \\
\text { to see the } \\
\text { universities to } \\
\text { be more } \\
\text { entrepreneurial. }\end{array}$ & $\begin{array}{l}\text { Does not } \\
\text { really reflect } \\
\text { the quality } \\
\text { of teaching } \\
\text { and research } \\
\text { institution. }\end{array}$ & $\begin{array}{l}\text { - The local } \\
\text { universities } \\
\text { have capable } \\
\text { researchers. }\end{array}$ & $\begin{array}{l}\text { - There is still } \\
\text { some room for } \\
\text { improvement } \\
\text { about the } \\
\text { efficiency of } \\
\text { procedures } \\
\text { within } \\
\text { universities. }\end{array}$ & $\begin{array}{l}\text { High } \\
\text { competitiveness } \\
\text { between } \\
\text { universities } \\
\text { and researchers } \\
\text { that limited } \\
\text { the culture of } \\
\text { partnerships. }\end{array}$ & $\begin{array}{l}\text { - Act as a } \\
\text { consultant for } \\
\text { both government } \\
\text { and industries, } \\
\text { especially in } \\
\text { the area based } \\
\text { on technical } \\
\text { expertise. }\end{array}$ \\
\hline $\begin{array}{l}\text { - Some } \\
\text { universities } \\
\text { are more } \\
\text { entrepreneurial } \\
\text { than others. }\end{array}$ & $\begin{array}{l}\text { The } \\
\text { effectiveness } \\
\text { of the } \\
\text { relationship } \\
\text { does not } \\
\text { depend on } \\
\text { the status } \\
\text { of the } \\
\text { universities. }\end{array}$ & $\begin{array}{l}\text { The main issue } \\
\text { is about the } \\
\text { flexibility and } \\
\text { the attitude of } \\
\text { the universities } \\
\text { towards change. }\end{array}$ & $\begin{array}{l}\text { Need to } \\
\text { reduce red } \\
\text { tape. }\end{array}$ & $\begin{array}{l}\text { Very much } \\
\text { depending on } \\
\text { the individual } \\
\text { staff. }\end{array}$ & $\begin{array}{l}\text { Universities are } \\
\text { places for } \\
\text { government } \\
\text { to implement } \\
\text { the policies. }\end{array}$ \\
\hline $\begin{array}{l}\text { Establishment } \\
\text { of the research } \\
\text { universities. }\end{array}$ & & $\begin{array}{l}\text { - Still lacking } \\
\text { in capability } \\
\text { and experience } \\
\text { in strengthening } \\
\text { the relationship } \\
\text { between } \\
\text { universities } \\
\text { and industries. }\end{array}$ & & & $\begin{array}{l}\text { More active } \\
\text { relationship in } \\
\text { commercialisation } \\
\text { of experts such } \\
\text { as education, } \\
\text { consultancy, } \\
\text { training and } \\
\text { development. }\end{array}$ \\
\hline $\begin{array}{l}\text { Required further } \\
\text { definition about } \\
\text { the status of } \\
\text { research } \\
\text { universities. }\end{array}$ & & & & & \\
\hline
\end{tabular}

Table 1: Summary of views on Malaysian universities drawn from the research fieldwork and interviews. 


\section{Issues and challenges facing universities in Malaysia}

Analysis of the information obtained through interviews shows the following seven main groups of issues and challenges which influence the development of the Triple Helix culture in the Malaysia and the role of universities in this context. Our findings are broadly consistent with that of other studies as is apparent from the discussion below of the various aspects of the issues and challenges facing universities in Malaysia.

\section{Technological factors}

Malaysian universities have not made much headway in the research and development of new and advanced technology such as fibre optic technology. As pointed out by a Senior Manager of a multinational company (MNC), most of the Malaysian universities perform weakly on the research and development front because they do not have the resources and the equipment that are crucial for the development new technologies. Nor, in his view, are most universities capable of readily providing industry needs as they do not have the relevant research expertise and experience. Schramm (2004) also notes that research especially in the life sciences, computing and engineering have not been successfully commercialised largely due to bureaucracy and the lack of applied skills and resources in universities. As a consequence of this situation, local industry in Malaysia has often had to resort foreign sources for R\&D assistance and support.

\section{Policies, procedures and processes within universities}

A major challenge for universities in Malaysia, as indeed elsewhere, is one of striking the right balance between the teaching and research responsibilities of their staff. This was borne out by our survey in which respondents from industry felt that universities were having problems in managing resources and time between research and teachings, and were also finding it difficult to hire the right staff for the right jobs because of the inflexibility underlying staffing policies. For instance, universities do not have enough experts in technology transfer, which is crucial for the development of relationships with industry. Furthermore, as a senior university management staff liaising with industry noted, the 40 per cent of staff time allowed for consultancy means it would take academic staff two years to complete a task that would take full-time staff a year or less. In view of this, it is not surprising that industry is somewhat nonchalant to engage the consultancy services of university staff.

\section{Commercialisation issues}

Commercialisation has always been an issue in the university-industrygovernment relationships. Many universities, however active in integrating their research and teaching activities, fall short of entrepreneurial behaviour and practice. This means forging links with industry and government does not necessarily make universities active agents in an evolving hybrid Triple Helix culture (Etzkowitz 2002). Our survey results show the following 
factors militating against the development of a hybrid Triple Helix culture in Malaysia: lack of entrepreneurs in Malaysia; lack of industry funding support for university research; rigid regulations and conditions that make it rather difficult for industry and universities to apply for loans to fund R\&D activities; and difficulties envisaged by universities in finding the right industrial partner. These problems have yet to be overcome for the social capital stock to increase and for sustainable growth to ensue with the emergence of innovative enterprises (Danell and Perrson 2003).

\section{Relationship/interaction issues}

Industry generally perceives university staff as being far removed from the practical problems it has to contend with. Universities are seen as ivory towers' preoccupied with issues of scarce relevance to real life situations. Often, though, such views are prejudicial and misconceived as there is evidence, however, fragmentary, that universities at least recognise that embedding enterprise in their research and teaching ethos is a necessary condition for their survival and growth. The persistence of the "ivory tower' stereotype view nonetheless remains a major factor in the weak university-industry link.

Another problem is that industry sometimes still considers that overseas researchers are superior to locals. Where industry has links with local universities, these are often forged on ad hoc basis. Meanwhile, several respondents from industry felt that industry should make the initiative to engage universities, but that for this to happen on a sustainable basis, the role of the government in providing policy guidelines would be crucial.

\section{Work cultures}

The difference in work cultures between the universities, industry and government is quite apparent. One of the main issues in work cultures is the response time (timeliness) especially in the interaction between the universities and industry. The CEO of a state investment agency highlighted delays in response time to be a major barrier in the university-industry relationship. Universities, it is argued, would need to fully comprehend the work culture in industry and be quicker in providing responses to industry lest industry loses interest in them. However, according to a senior manager of a university's commercial arm: 'Industry wants things done very quickly at their time but we insist that we can only do it on our terms because we are teaching ... unfortunately teaching is the major duty for Malaysian academics, whether we like it or not'.

\section{Intellectual property (IP) issues}

The Malaysian government has a plan to set up a broad IP policy. However, some concerns about the clarity of this policy and its guidelines have been expressed by representatives from the main stakeholders - the university sector, the government and industry. According to one senior government official, IP issues constitute the most important barrier in the 
relationship between the universities, industry and the government. Although there is policy guideline for 50/50 partnership arrangements, the IP policy for the industry and universities is confused, and IP awareness in Malaysia is still low.

\section{Government policies}

It is widely recognised that government policy has a strong bearing on the effectiveness of the role of universities in the socio-economic development process (Gibbons 1998). In Malaysia, the government has taken initiatives to establish research universities with the view to enhancing the knowledge base of the economy. However, as brought our by our survey, this endeavour is constrained by the inflexibility, inconsistency, rigidity, vagueness and lack of direction of policy. One senior government officer stressed that the country needs clear direction and the ministries should communicate with one another to make sure there is a focus in policy direction. He said:

We have so many policies - education policy, and science and technology policy. Right now we have less than 16 scientists per 10,000 people and we want to get 20 scientists per 10,000 . What we have to do in order to achieve that is not clear - every ministry is doing its own things.

Saad (2004) argued the case for effective governance to enhance the evolutionary process in the triple Helix system. This is certainly true for Malaysia, especially with respect to the administration of universities which is encumbered with the inflexibility of bureaucratic culture.

\section{Positioning Malaysian universities within the Triple Helix transition framework}

Most Malaysian universities are positioned within either the statist or lassiezfaire Triple Helix categories. The Triple Helix system has yet a long way to evolve. Meanwhile, universities are still struggling to fulfil their role as entrepreneurial institutions. The government remains a dominant actor, and is often seen dictating and imposing ambiguous and unclear terms on the other actors. Even though there is evidence of universities in Malaysia having an active relationship with industry, this is limited to educational development and ad hoc consultancy activities. Universities are nonetheless still struggling to find industrial partners and to commercialise their research. However, R\&D collaboration between universities and the industry has not yet reached a satisfactory level.

The Malaysian government continues to act as the dominant sphere in the development of knowledge and innovation. Both academia and industry remain dependent upon the government for overall coordination, specification of objectives, planning and provision of resources. This corresponds to a statist type Triple Helix. However, it is important to note that most Malaysian universities are no longer acting as just teaching 
institutions since they are also conducting research, setting up incubators (with strong support from the government), thus playing a role in the sphere of industry. They are also striving to establish lasting relationships with industry. But what is apparent in the Triple helix evolution to date is an 'arms length' relationship between industry and universities, a phenomenon categorised as laissez-faire Triple Helix (Etzkowitz 2003). There is no evidence to suggest that the university-industry relationship in Malaysia would soon evolve into the hybrid Triple Helix category. Universities are not yet entrepreneurial enough and are still unable to fully assume the role of industry, especially in commercialising their research. Industry is rather cautious and risk averse with respect to its relationship with local universities. The development of social capital and hence the transition to hybrid Triple Helix would very much depend on how policy evolves to tackle institutional/cultural rigidities and bottlenecks that have hitherto stunted the evolutionary process of the Triple helix system in Malaysia.

\section{Conclusion}

Overall, though, Malaysian universities have made a significant effort to promote the evolution of the triple Helix culture. However, there are still key issues to be addressed and challenges to be faced. Universities in Malaysia still rely on the government for resources (financial and human). Some university staff members also seem reluctant to swallow wholesale the idea of a university being entrepreneurial since, for them, universities exist to uphold social responsibilities (such as the provision of higher education in the groves of academe) and not to be busily engaged in commercial ventures. Universities in Malaysia would, however, need to be more flexible and would, for this reason, require more autonomy from the government. This will enable them to make quick decisions in response to changing industry need profiles and to become more competitive and effective.

As the triple helix culture evolves, government, industry and universities would need to work in collaboration with one another. Efforts should be made to address issues such as commercialisation, IP policy and work cultures. It is apparent from our investigation that the situation has been improving over the past 10 years with the introduction of policies aimed, to a certain extent, to strengthen the role of universities and their links with their immediate external. However, the overriding view is that there is still a long way to go, and that for this to be realised, a strong commitment from all parties would be needed.

\section{References}

Anselin, L., Varga, A. and Acs, Z.J. (2000), 'Geographical Spillovers and University Research: A Spatial Economelric Perspective', Growth and Change, 31: 4, pp. 501-515.

Aronson, J. (1994), 'A Pragmatic View of Thematic Analysis,' The Qualitative Report, 2: 1, Spring, available from http://www.nova.edu/ssss/QR/BackIssues/QR2-1/ aronson.html (Accessed 1 June 2007). 
Bjamason, S. (2003), The Idea of Engagement, London: ACU.

Blaikie, N. (2000), Designing Social Research, Cambridge: Polity Press.

Branscomb, L. and Keller, J. (1999), Investing in Innovation. Creating a Research and Innovation Policy that Works, Cambridge, MA: MIT Press.

Bryman, A. (1988), Quantity and Quality in Social Research, London: Unwin Hyman.

Campbell, A. (2005), 'The Evolving Concept of Value Add in University Commercialisation', Journal of Commercial Biotechnology, 11: 4, pp. 331-345.

Castells, M. and Hall, P. (1994), Technopoles of the World: The Making of 21st Century Industrial Complexes, London: Routledge.

Charles, D. (2003), 'Universities and Territorial Development: Reshaping the Regional Role of UK Universities,' Local Economy, 18: 1, pp. 7-20.

Coffield, F. and Williamson, W. (1997), Repositioning Higher Education, Buckingham: Open University Press.

Cooke, P. (2002), 'Regional Innovation Systems: General Findings and Sonic New Evidence from Biotechnology Clusters', Journal of Technology transfer, 27: 1, pp. 133-145.

Danell, R. and Persson, O. (2003), 'Regional R\&D Activities and Interactions in the Swedish Triple Helix,' Scientometrics, 58: 2, pp. 205-218.

DTI/DIEE (Department of Trade and Industry/Department For Education and Employment) (2001), Opportunity For All In a World of Change: A White Paper On Enterprise, Skills And Innovation, London: HMSO.

Etzkowitz, H. (2003), 'Innovation in Innovation: The Triple Helix of UniversityIndustry-Government Relation', Social Science Information, 42: 3, pp. 293-338.

(1994), 'Academic-Industry Relations: A Sociological Paradigm for Economic Development,' in H. Etzkowitz and L. Leydesdorff (eds.), Universities in the Global Knowledge Economy: The Triple Helix of University-Industry-Government Relations, London: Cassell Academic.

Etzkowitz, H. and Klofsten, M. (2005), 'The Innovating Region: Toward a Theory of Knowledge-Based Regional Development', RED Management, 35: 3, pp. 243-255.

Etzkowitz, H. and Leydesdorf, L. (1999), 'The Future Location of Research and Technology Transfer,' Journal of Technology Transfer, 24: 2-3, pp. 111-123.

(1997), Universities in the Global Knowledge Economy: The Triple Helix of University-Industry-Government Relations, London: Cassell Academic.

(1995), 'The Triple Helix: University-Industry - Government Relations. A Laboratory for Knowledge Based Economic Development,' EASST Review. European Society for the Study of Science and Technology, 14: 1, pp. 18-36.

(2001), 'The Transformation of University-Industry-Government Relations', Electronic Journal of Sociology (online), 5: 4, available from http://www.sociology. org/archive.html (Accessed 1 May 2007).

- (1998), 'The Triple Helix as a Model for Innovation Studies', Science and Public Policy, 25: 3, pp. 195-203.

(2000), 'The Dynamics of Innovation: from National Systems and Mode 2 to Triple Helix of University-Industry-Government Relations', Research Policy, 29: 2, pp. 109-123.

Etzkowitz, H. (2002), 'Incubation of Incubators: Innovation as a Triple Helix of University-Industry-Government Networks,' Science and Public Policy, 29: 2, pp. $115-128$.

Freeman, C. and Perez, C. (1988), 'Structural Crises of Adjustment, Business Cycles and Investment Behaviour', in G. Dosi, C. Freeman, R. Nelson, G. Silverberg and L. Soete (eds.), Technical Change and Economic Theory, London: Pinter. 
Fritsch, M. and Slavtchev V. (2007), 'Universities and Innovation in Space,' Industry and Innovation, 14: 2, pp. 201-218.

Fujigaki, Y. and Nagata, A. (1998), 'Concept Evolution in Science and Technology Policy: The Process of Change in Relationships Among University, Industry and Government', Science and Public Policy, 26: 6, pp. 387-395.

Gellner, E. (1994), Conditions of Liberty: Civil Society and Its Rivals, Harmondsworth: Penguin.

Gibbons, M. (1998), Higher Education Relevance in the 21st Century, London: ACU.

Gibbons, M., Limoges, C., Nowotny, H. and Schwartzman, S. (1994), Production of Knowledge - The Dynamics of Science and Research in Contemporary Societies, London: Sage.

Goddard, J. and Chatterton, P. (1999), 'Regional Development Agencies and the Knowledge Economy: Harnessing the Potential of Universities,' Environment and Planning C: Government and Policy, 17: 6, pp. 685-699.

Godin, B. and Gingras, Y. (2000), 'The Place of Universities in the Knowledge Production', Research Policy, 29: 2, pp. 273-275.

Gulbrandsen, M. (1997), 'Universities and Industrial Competitive Advantage', in H. Etzkowitz and L. Leydesdorff (eds.), Universities in the Global Knowledge Economy: The Triple Helix of University-Industry-Government Relations, London: Cassell Academic.

Gunasekara, C. (2004), 'The Third Role of Australian Universities in Human Capital Formation,' Journal of Higher Education Policy and Management, 26: 3, pp. 329-343.

Henry, N. and Pinch, S. (2000), 'Spatialising Knowledge: Placing the Knowledge Community of Motor Sport Valley', Geoforum, 31: 2, pp. 191-208.

Holland, B. (2001), 'Toward a Definition and Characterization of the Engaged University,' Metropolitan Universities, 2: 3, pp. 20-29.

Karisson, C. and Zhang, W. (2001), 'The Role of Universities in Regional Development Endogenous Human Capital and Growth in a Two-Region Model,' The Annals of Regional Science, 35: 2, pp. 179-197.

Leininger, M.M. (1985), 'Ethnography and Ethnonursing: Models and Modes of Qualitative Data Analysis', in M.M. Leininger (eds.), Qualitative research methods in nursing, Orlando, FL: Grune \& Stratton.

Macpherson, A. and Ziolkowski, M. (2005), 'The Role of University-Based Industrial Extension Services in the Business Performance of Small Manufacturing Firms: Case-Study evidence from Western New York,' Entrepreneurship and Regional Development, 17: 6, pp. 431-447.

Malairaja, C. (2003), 'Learning from the Silicon Valley and Implications for Technological Leapfrogging - The Experience of Malaysia,' The International Journal of Technology Management and Sustainable Development, 2: 2, pp. 73-95.

Mavin, S. and Bryans, P. (2000), 'Management Development in the Public SectorWhat Roles Can Universities Play?' The International Journal of Public Sector Management, 13: 2, pp. 142-152.

Miles, M. and Huberman, A. (1994), Qualitative Data Analysis, London: Sage, Second Edition.

OECD (1999), Public and Private Partnership in Science and Technology: An Overview, Paris: OECD.

Pires, A. and Castro, E. (1997), 'Can a Strategic Project for a University be Strategic to Regional Development?', Science and Public Policy, 24: 1, pp. 15-20.

Readings, B. (1996), The University in Ruins, Cambridge, MA: Harvard University Press. 
Ritchie, J. and Lewis, J. (2003), Qualitative Research Practice: A Guide for Social Science Students and Researchers, Thousand Oaks, CA: Sage.

Rip, A. and Meulen, B. (1996), 'The Post-Modern Research System', Science and Public Policy, 23: 6, pp. 343-352.

Saad, M. (2004), 'Issues and Challenges Arising from the Application of Innovation Strategies Based on the Triple Helix Culture: Experience of the Incubation System in Algeria,' International Journal of Technology Management and Sustainable Development, 3: 1, pp. 17-35.

Saad, M. and Zawdie G. (2005), 'From Technology Transfer to the Emergence of a Triple Helix Culture: The Experience of Algeria in Innovation and Technological Capability Development', Technology Analysis \& Strategic Management, 17: 1, pp. 1-15.

Saunders, M., Lewis, P. and Thornhill, A. (2000), Research Methods for Business Students, Harlow, Pearson: Education Limited.

Schramm, C.J. (2004), 'Accelerating Technology Transfer and Commercialisation', paper presented at IP Commercialisation and Research Spinouts Conference, Boston, Massachusetts, November 4.

Sharma, M., Kumar, U. and Lalande, L. (2006), 'Role of University Technology Transfer Offices in University Technology Commercialization: Case Study of the Carleton University Foundry Program', Journal of Services Research, 6, Special Issue, pp. 109-139.

Sutz, J. (2000), 'The University-Industry-Government Relations in Latin America', Research Policy, 29: 2, pp. 279-290.

Taylor, S.J. and Bogdan, R. (1984), Introduction to Qualitative Research Methods: The Search for Meanings, New York: John Wiley and Sons.

The Sunday Star (2007), 'Boost for Research,' The Sunday Star, Kuala Lumpur: Sunday, August 19, p. 4.

Varga, A. (1998), University Research and Regional Innovation: A Spatial Econometric Analysis of Academic Technology Transfers, Boston, MA: Kluwer Academic Publishers.

Yin, R. (1994), Case Study Research, Design and Method, London: Sage.

\section{Suggested citation}

Razak, A., \& Saad, M. (2007), 'The role of universities in the evolution of the Triple Helix culture of innovation network: The case of Malaysia', International Journal of Technology Management and Sustainable Development 6: 3, pp. 211-225, doi: 10.1386/ijtm.6.3.211/1

\section{Contributor details}

Azley Abd Razak is Research and Teaching Associate in the Bristol Business School, School of Operations and Information Management, at the University of West of England in Bristol. Contact: Bristol Business School, School of Operations and Information Management, University of West of England, Bristol, BS16 1QY UK. E-mail: Azley.Abdrazak@uwe.ac.uk

Dr. Mohammed Saad is Reader in the Bristol Business School, School of Operations and Information Management, at the University of West of England in Bristol. Contact: Bristol Business School, School of Operations and Information Management, University of West of England, Bristol, BS16 1QY UK.

E-mail: Mohammed.Saad@uwe.ac.uk 
Copyright of International Journal of Technology Management \& Sustainable Development is the property of Intellect Ltd. and its content may not be copied or emailed to multiple sites or posted to a listserv without the copyright holder's express written permission. However, users may print, download, or email articles for individual use. 